UDC: 821.111.09-31 Ишигуро К.

\title{
- HUMAN CONDITION IN KAZUO ISHIGURO'S NEVER LET ME GO
}

\author{
ZLATA LUKIĆ 1 \\ University of Belgrade, \\ Faculty of Philology, English Department, \\ Belgrade, Serbia
}

Cilj ovog rada je da, kroz sveobuhvatnu psihološku i sociološku analizu likova u romanu Ne daj mi nikada da odem Kazua Išigura, ukaže na to kako uloge, pravila, rutina i navike, kao rezultat spoljašnjeg pritiska ili sopstvenih unutrašnjih stega, u krajnjoj liniji od čoveka uzimaju ono najbolje, čineći njegov život ispraznim i površnim. Ǐsigurovi likovi - klonovi čiji život služi „višoj" svrsi, odličan su primer za to koliko je lako zaboraviti u čemu je suština ljudskog postojanja, koliko je lako potonuti u beznađe ljudske tragedije, odnosno, kako je Išiguro sam jednom prilikom rekao - „„̌̌alosnog čovekovog stanja“. Oslanjajući se na studiju Džona Djuija (John Dewey) pod nazivom Ljudska priroda i ponašanje, kao i na takozvanu „teoriju uloga", ovaj rad se bavi odnosom društvenih uloga i privatnog života, temama pasivnosti i potiskivanja osećanja, pri čemu se pokušavaju pronaći odgovori na ključna pitanja: zašto se klonovi ne pobune i šta im to nedostaje da bi bili ljudi.

Ključne reči: društvene uloge, navike, pasivnost, represija, imitacija života, pobuna, ljudskost, potiskivanje osećanja.

\section{INTRODUCTION}

One of the greatest contemporary writers today, Kazuo Ishiguro (1954- ), whose worldwide fame rests on the novels like The Remains of the Day (1989), The Unconsoled (1995), and When We Were Orphans (2000), seems to be incurably enchanted by the unfathomable depths of the human soul. In each of his brilliant novels, Ishiguro deals with the universal themes of love, freedom and happiness, along with the crucial life decisions, unstoppable passage of time, and unreliability of human memory. In many of his novels he also plays with the idea that habits, patterns and social roles ultimately define who we are. This is particularly the case, for instance, in his masterpiece The

1 Kontakt podaci (Email): zlatalukic@gmail.com 
Remains of the Day, whose protagonist, Mr Stevens, realizes - unfortunately all too late - that his stubborn and unswerving professionalism cost him a fulfilling private life and personal happiness. In his latest novel, Never Let $\mathrm{Me} \mathrm{Go}^{2}$, Ishiguro takes things one step further, experimenting with the genre of dystopian and science fiction novel, but nevertheless, remains faithful to his distinctive style and predominant themes.

Attracted by this powerful combination - strange, yet typical for Ishiguro - in this paper we try to illustrate, through a comprehensive psychological and sociological analysis of characters in NLMG, how passivity, roles, rules, habits, and routines, imposed either externally or internally, ultimately take the better of us, making our lives empty and superficial. Ishiguro's characters, Kathy, Ruth, and Tommy, parentless clones with a "higher" purpose in life, stand as perfect examples of how easy it is to forget what human existence is all about, how easy it is to sink into the bottomless sea of human tragedy, or, as Ishiguro himself put it in one of his interviews - "the sadness of the human condition" (Ishiguro n.d.).

The clones from NLMG share the same tendency, bordering on obsession, to pursue the wrong goals, burying their feelings along the way under the heavy burden of habit, routine, and, ultimately, repression and denial. "This is a recurring element in Ishiguro's fiction; and surely an indispensable aspect of his vision. As he would have it, we are all trapped, whether in institutions or by mores or in a fantasy logic or in the past. His characters cannot jump out the window, because they do not believe there is anything outside the window to jump into." (Messud 2005) Taking this into account, we focused on the psychological framework of the protagonists of NLMG, elaborating on their behaviour, character, ideals and choices, our main references being various, insightful reviews of the concerned novel, studies on Ishiguro and his work, critical essays and applicable theories in the field of social psychology. In particular, we will be referring to John Dewey's Human Nature and Conduct, and the so-called "role theory"3.

The first chapter of the paper, "Something About the Clones", sheds light on the basic relations among the three main characters - Kathy, Ruth and Tommy, at the same time stressing the crucial problem, i.e. passivity and submissiveness of the clones. The paper goes on to deal with the theme of emotional repression and the clones' poignant imitation of life in the chapter titled "Why Can't They Be Human?", followed by an equally relevant issue of "Why Don't the Clones Rebel?". The final chapter, resorting to the so-called "role theory", provides a juxtaposition of the social role and private life of the clones, examining the above ideas from yet another - sociological - perspective.

\section{SOMETHING ABOUT THE CLONES}

Kathy, the narrator of the story, introduces herself in the very first sentence of the novel, the beginning of which, in general, contains no indication of the true state of

2 To be abbreviated hereafter as NLMG.

3 Also, in light of the recently premiered movie Never Let Me Go, based on Ishiguro's novel and directed by Mark Romanek, starring Carey Mulligan, Andrew Garfield and Keira Knightley, we will draw occasional parallels throughout the paper between the book and the movie. 
affairs. Only later in the novel do we discover that Kathy is a clone, raised in Hailsham, in a controlled environment, where "students" are taught by their surrogate parents - "guardians" to take care of their physical health, and encouraged to express their creativity through art. In her early recollections of the place, Kathy seems to be proud of the fact that she grew up in the sophisticated Hailsham, instead of some other gruesome place. As a matter of fact, she considers herself "lucky" (Atwood 2005), even though this strikes the reader as an absurd contradiction with what the fate keeps in store for the clones. This evidently shows how everything in life depends on the perspective one chooses to look at it from, i.e. essentially on one's own attitude towards things. Thus, one can practically turn even the worst possible scenario into a good one just by being positive about it. In his study Human Nature and Conduct, John Dewey describes an interesting idea - a metaphor, actually - originally expressed by Tolstoi, which perfectly relates to the above concept:

[...] [H]e said that the ox is a slave as long as he refuses to recognize the yoke and chafes under it, while if he identifies himself with its necessity and draws willingly instead of rebelliously, he is free. But as long as the yoke is a yoke it is impossible that voluntary identification with it should occur. Conscious submission is then either fatalistic submissiveness or cowardice. The ox accepts in fact not the yoke but the stall and the hay to which the yoke is a necessary incident. But if the ox foresees the consequences of the use of the yoke, if he anticipates the possibility of harvest, and identifies himself not with the yoke but with the realization of its possibilities, he acts freely, voluntarily. He hasn't accepted a necessity as unavoidable; he has welcomed a possibility as a desirability. (Dewey 1957: 285-286)

Kathy herself shows a considerable degree of natural curiosity, but she never "explicitly poses meta-questions about the justice of the clone-discourse's existence" (Mohr 2008: 21). On a personal level, too, Kathy never questions anything, even when it implies being maltreated by her friend Ruth or suppressing her feelings for Tommy. Instead of standing up for herself, even when Ruth manipulatively instigates a fight between her and Tommy, Kathy, typically, walks away, choosing to remain a passive onlooker, behaving "as though nothing special had occurred" (Ishiguro 2005: 194), until the point when Ruth, dying, guilt-ridden, practically gives her a go-ahead to date Tommy: "It should have been you two. I'm not pretending I didn't always see that. of course I did, as far back as I can remember. But I kept you apart. [...] What I want is for you to put it right. Put right what I messed up for you." (Ishiguro 2005: 228, italics used for emphasis).

Kathy's entire life (and the life of other clones, for that matter) has been marked by "double repression" - not only does she repress the knowledge about her future, encouraged by her guardians, but she also represses her own emotions, which is clearly illustrated on many occasions throughout the novel. For instance, there is a poignant moment when she goes with Tommy on a search for her long-lost, favourite music tape: "Then suddenly I felt a huge pleasure - and something else, something more complicated that threatened to make me burst into tears. But I got hold of the emotion, and just gave Tommy's arm a tug." (Ishiguro 2005: 170) On yet another occasion, later 
in the novel, Kathy remembers a fight with Tommy: "[...] and I suppose by now I was furious, but I kept my voice quiet and under control" (Ishiguro 2005: 275, italics used for emphasis). Therefore is the last scene of the novel her one and only "revealing indulgence" (Cappo 2009: 55). All the feelings Kathy had been suppressing for years finally emerged, if only for a brief moment. And even then, she cannot suppress the urge to somehow justify her, more than human, emotions to the reader: "That was the only time, as I stood there, looking at that strange rubbish, feeling the wind coming across those empty fields, that I started to imagine just a little fantasy thing, because this was Norfolk after all, and it was only a couple of weeks since I'd lost him." (Ishiguro 2005: 282, italics used for emphasis).

Finally, the last two sentences, written with utmost care and abundant with meaning, read as follows: "The fantasy never got beyond that - I didn't let it - and though the tears rolled down my face, I wasn't sobbing or out of control. I just waited a bit, then turned back to the car, to drive off to wherever it was I was supposed to be." (Ishiguro 2005: 282, italics used for emphasis). That Kathy did not let the fantasy develop further implies strength of will, control and intention on her part, which is explicitly confirmed only a couple of phrases later, within the same sentence. It was already against her principles that she was crying, so she needed to underline that she was not sobbing, and that everything was (seemingly) in hand. She had everything under control. She always did. Obediently, just as if she were still under the strict eye of one of her childhood guardians, Kathy walks back to her car, and drives off. Strikingly, not to wherever she wishes to be, but to wherever she is supposed to be. The thoughts and behaviour of other clones - Ruth and Tommy - strikingly follow the same fashion. Thus, for instance, on one occasion, discussing the donors and carers, Ruth exclaims: "I was pretty much ready when I became a donor. It felt right. After all, it's what we're supposed to be doing, isn't it?" (Ishiguro 2005: 223, italics in the original). The expression - subtle, yet powerful - of their passivity and submissiveness.

\section{WHY CAN'T THEY BE HUMAN?}

Unfortunately, Kathy, Ruth and Tommy seem to be suffering from the same kind of paralysis that other Ishiguro's characters typically exhibit. Kathy keeps suppressing her obvious feelings for Tommy, letting Ruth come between them time and again, and at times even acts as an intermediary between Ruth and Tommy, when the two start dating. Ruth, on the other hand, tries - not always successfully - to suppress her jealousy of Kathy, which incites her to various forms of manipulation and scheming. Finally, Tommy tries to suppress his completely justified, but powerless bursts of rage, in order to meet the standards and avoid being mocked by the rest of the clones. However, just like Cappo observes, although Kathy's emotional repression at times seems inhuman, it also, paradoxically, serves as confirmation of her humanity. In general, that the clones' emotions are so repressed makes them robotic, but underneath the repression, their emotions are painfully human (Cappo 2009: 55). In other words, Kathy, Ruth and Tommy are the clones who, while by default thought to be "emotionless", ironically prove to be human by suppressing their emotions. Still, no matter how hard these tragic figures 
try to fully suppress their emotions, and lead their sorrowful lives without thinking about which opportunities they have lost, these emotions sooner or later erupt to the surface because: "[s]uppression is not annihilation. 'Psychic' energy is no more capable of being abolished than the forms we recognize as physical. If it is neither exploded nor converted, it is turned inwards, to lead a surreptitious, subterranean life." (Dewey 1957: 146-147). As far as the clones are concerned, the latter is the case. And it is only too late that they realize things could have been different.

In his review of NLMG, Louis Menand makes an interesting point about Ishiguro's characters, comparing their "mad, compulsive, quasi-mechanical qualities" with those of Beckett's characters: "There is something animatronic about them. They are simulators of humanness, figures engineered to pass as 'real'. What it means to be really human is always a problem for them. Can you just copy other people? Would that take care of it?" (Menand 2005). And, sure enough, the characters in NLMG are obviously having difficulties trying to adapt to what is considered "normal" - i.e. trying to become more like the "normals", as they ironically refer to the "real" people. This idea is highlighted by means of role-plays that the students enact as part of their regular schooling activities, during the so-called Culture Briefings. Just like Puchner observes, in NLMG "cultural imitation characterizes the clones through and through. Their language, gestures, and forms of interaction are secondhand, like the tapes, movies and objects they receive from the outside world." (Puchner 2008: 45). They are taught how to behave in ordinary, everyday situations - in a café, for instance - but when they actually take a trip to the "real world", anxious and baffled, they still behave conspicuously odd.

Ishiguro underlines this idea by taking the story to the extreme - his characters are literally not human, being clones instead, "programmed to pick up 'personhood skills"' (Menand 2005). They entirely meet the concept of "copies", with all the implications of "watered down, pale imitations of the original" and "photocopies of photocopies" (Cappo 2009:51). It is interesting to note that some authors find the connection between the way Kathy narrates her story, i.e. between her detached and "deeply unsettling blandness" and the idea that she sounds like a somewhat deficient, "manufactured creature" (Puchner 2008: 35). This observation gains some more ground in light of the remark that Kathy utters in passing at the very second page of the novel, namely that "[c]arers aren't machines"4 (Ishiguro 2005: 4).

The clones' poignant desire to get closer to the realm of humans is reflected in another form of imitation - imitation of biological family (Puchner 2008: 44). Essentially orphans, while in Hailsham, the clones are constantly seeking approval from the guardians, a "pat on the head", so to speak. Once they grow up and move to the Cottages, this need is manifested through their fervent search for "possibles", i.e. the humans that might be their originals. Thus, they organize a trip to Norfolk, where some older clones allegedly saw the potential Ruth's "possible". The trip, however, turns out to be a huge disappointment, although Ruth, again typically, refuses to admit how important the whole event is for her: "'To be honest', she said, 'I knew all along it was stupid."' (Ishiguro 2005: 164).

4 Which, interestingly enough, stands in stark contrast with Kathy's straightforward statement from the very beginning of the movie: "We are machines!" 
The theme of "copying" recurs once the clones start living at the Cottages, where the new-comers, like Ruth and Tommy, start imitating the mannerisms of the "veterans", i.e. older students. Ruth, in particular, has a strong desire to blend in, driven by her fear of being different. Therefore, she copies the gestures she notices in actors from television series, as the only available representatives of "normal" people. In a word, the clones represent the imitation of life, both in the literal and metaphorical sense. Hence, like Wood aptly observes, "[w]e begin the novel horrified by their difference from us and end it thoughtful about their similarity to us!" (Wood 2005). Maybe that is the reason why the final farewell between Kathy and Tommy ${ }^{5}$, with a small kiss and no fuss, both heartrending and frustrating, makes the reader feel like sobbing and screaming with rage at the same time: "Why don't you do something? Why don't you rebel?!" And why don't they?

\section{WHY DON'T THE CLONES REBEL?}

Think of Kathy H. for a moment, and all her friends - they have been raised to read and discuss the masterpieces of literature, express their creativity through different kinds of art, ride a car, take care of themselves. Even the slightest thought of having a true life, and being an independent and happy individual was nipped in the bud by their guardians. And despite all the education they received, despite all the urges and youthful desires, they never even dare consider the idea of escape. They never contemplate rebellion. Just like Messud (2005) notes: "There is great dignity in Kathy $H_{\text {., }}$ and in her friends. There is also, ultimately, a pained and painful resignation. [...] [T] he Hailsham students seem, for all their musing, not to ask the essential question: Does it have to be this way?" Having been brainwashed from their early childhood, the wretched clones have learned to suppress their emotions, their dreams about meeting their "possibles", building professional careers, and leading a long, healthy life. Their life has been cut out for them by somebody else and they never get a chance to challenge that somebody. Though the feeling is that, even if they had that chance, they would probably hesitate to seize it.

To be fair, once they find out about the possibility to "defer" their donations for a couple of years because they are truly in love, Kathy and Tommy do go and confront Madam and Miss Emily, but, once they realize, to their immense disappointment, that the rumour was false, they both sink into the well of despondency and just let it all go. One is left frustrated by the inability to grasp the notion that Kathy and Tommy do not, even for a second, think that they might simply run away. After all, who is there to stop them? From what we understand from the story, there is nothing to physically distinguish the clones from the real people, and, given their education and manners, they could easily blend in with the crowd. When they visit the art gallery during the trip to Norfolk, they lead a perfectly civil conversation with the proprietor, and it

5 Their final farewell - one of the most powerful and unsettling scenes in the movie - shows Kathy who is, upsettingly calm, with a bleak smile on her face, standing behind the separation glass in the sterile setting of a hospital, watching Tommy being prepared for his last donation surgery. 
seems that it is only their own feeling of oddness and abnormality that functions as a restraint.

Just like James Wood aptly notices: "Full comprehension of who they are and why they were created makes them sad, but only resignedly so. This is the only reality they have ever known, and they are indeed creatures of habit." (Wood 2005). To further illustrate the concept of habit and how powerful its grip may be, we hereby quote John Dewey's, quite pertinent, definition of it:

[Habits] operate in two ways upon intellect. Obviously, they restrict its reach, they fix its boundaries. They are blinders that confine the eyes of mind to the road ahead. They prevent thought from straying away from its imminent occupation to a landscape more varied and picturesque but irrelevant to practice. [...] [H]abit made complete in routine shuts in thought so effectually that it is no longer needed or possible. (Dewey 1957: 163-164)

Even when they start living at the Cottages, where they enjoy much more freedom, the clones barely ever exercise it. Apart from their trip to Norfolk, Kathy and her friends rarely leave the Cottages, whiling their days away discussing literature and walking in the nearby fields. "They possess individuality, and seem to enjoy it (they fall in love, they have sex, they read George Eliot), but that individuality is a mirage, a parody of liberty." (Wood 2005) The inhabitants of Ishiguro's world - the clones - are not physically trapped or restrained. ${ }^{6}$ Having been subjected to subliminal indoctrination, the clones have accepted their fate, and, what is worse, they "do not even recognize their attitude as that of acceptance" (Puchner 2008: 40). They have become the prisoners of their own frame of (brainwashed) mind.

\section{SOCIAL ROLE VERSUS PRIVATE LIFE}

One of the things that the clones in NLMG have in common is their devotion to the role they play in the social context, the devotion so strong that it threatens to damage, and actually damages, their private life. To elaborate on this, we will resort to a branch of the sociological theory dealing with social roles, the so-called "role theory", a fruitful approach to understanding humans and society. For the purposes of this paper, we will mention only one of the extensions to it, i.e. the concept of "role embracement", which may serve as another potential explanation for the total absence of rebellious spirit on the part of the clones.

Role Embracement refers to the complete adoption of a role. When a role is truly embraced, the self disappears completely into the role. Three things seem to be

6 Interestingly enough, though, the clones in the movie wear special bracelets with chips for checking in and out of the premises, which was, presumably, the director's way of underlining their similarity with robots. At the same time, the bracelets add the aspect of physical restraint - which is totally absent from the book - thus shedding a new light on the idea of a rebellion. 
involved in the earnestness with which people assume roles or the degree to which they embrace a role:

1. An admitted or expressed attachment to the role;

2. A demonstration of qualifications and capacities for performing it;

3. An active engagement or spontaneous involvement in the role activity at hand, that is, a visible investment of attentions and muscular effort. (Sociological Theory n.d., italics used for emphasis)

One may easily see that Kathy (and clones in general) perfectly fits the above definition, though, admittedly, the situation in NLMG is somewhat specific, since the clones have their roles imposed to them by the society. Other than that, the pattern is the same, and is now brought to the extreme. The clones are fully identified with their role - they have absolutely no other purpose in life other than donating organs time after time until they "complete", i.e. die.

Another interesting point in terms of roles ${ }^{7}$ is that "[f]rom the very beginning of their existence, there has been one single word to which the clones tie their identity, one word that captures the meaning of their existence - students." (Mohr 2008: 36, italics in the original). The clones have been taught all their lives what the role of a Hailsham student implies, how they should behave, what they should and should not do. This is so deeply embedded in their inner feeling of self that even many years after they leave Hailsham, Kathy and Tommy still play the same submissive role of students when they are faced with Madam and Miss Emily towards the end of the novel: "She reached out and put her hands on the backs of two matching armchairs just in front of her. [...] When we turned to sit down, she was over by the window, in front of the heavy velvet curtains, holding us in a glare, like we were in class and she was a teacher." (Ishiguro 2005: 246, italics used for emphasis).

Likewise, Kathy embraces the role of a carer, which, for her, conveniently offers a sort of escape from the painful and complex relationship with Ruth and Tommy. Moreover, Kathy prides in being a good carer, in her role and good records, as well as the fact that she can pick her own patients. It is interesting to note that Ruth and Tommy want to get it over as soon as possible - as if they rushed into death as their only salvation. Kathy, on the other hand, clings to her role as a carer, and rejects the idea of becoming a donor so soon: "[...] it's important there are good carers. And I'm a good carer. [...] A good carer makes a big difference to what a donor's life's actually like." (Ishiguro 2005: 276). Once again we witness how important roles can be in one's life, and how sometimes one can use them as an excuse for not dwelling too much on the other, undoubtedly more deserving, aspects of one's life - i.e. as a justification for neglecting one's private life, and one's feelings. On the other hand - given the circumstances - their roles, in combination with the absurd, yet poignant belief that they have devoted their lives to a "higher cause", are the only things keeping Ishiguro's characters floating, the only things making the otherwise harsh and unbearable reality bearable.

7 In his paper "When We Were Clones", Puchner refers to roles as "functionalities", in which he sees one differentiating factor between the humans and the clones. The second, much starker difference, is the fact that the clones cannot reproduce. 


\section{CONCLUSION}

"...even when happiness is standing right in front of you, it's very hard to grasp" (Menand 2005)

In the broadest sense, one may say that NLMG actually deals with the three major and most universal themes - those of love, freedom and happiness. It raises essential questions in the vein of: What is happiness? How do we achieve it? How empty and futile our life is without love? What is it that makes us free? Why is it so difficult to communicate our feelings?

Ishiguro provides no definite answers, because there can hardly be any. What he does provide, however, is a different perspective. The one through which the reader realizes that the clones are inactive to the point it almost looks like they are nothing but passive observers of their own lives. They seem to be enjoying not having to dwell on crucial decisions in their lives. Why would Kathy bother about (re-)shaping her life, when the powers-that-be have already done the job for her? Why would Ruth fulfil her dream of becoming a business woman, when her destiny has already been predefined for her? Why would Tommy preserve his identity, when it is so difficult to be unique, and so much easier to blend in the crowd? This inability, and maybe even unwillingness, to shape the events in their lives is what prevents Ishiguro's characters from building their own happiness actively. Just like Mr Stevens in The Remains of the Day, and the protagonists of other Ishiguro's novels, the clones in NLMG will painfully continue to follow the rules even at the highest price - that of love and personal contentment, this passivity perhaps being best reflected in the fact that "Tommy's most outspoken outcry against a monstrous status quo is to say twice that 'it's a shame'" (Kemp 2005). Unfortunately, it is already too late when Ruth realizes that she made a mistake not having tried to fulfil her dreams, when Tommy regrets not having invested more effort into developing his creativity, and when Kathy laments on the time she and Tommy wasted, not having fought for their love sooner: "So that feeling came again, even though I tried to keep it out: that we were doing all of this too late; that there'd once been a time for it, but we'd let that go by, and there was something ridiculous, reprehensible even, about the way we were now thinking and planning." (Ishiguro 2005: 237)

Even though at the first glance it may seem that the central theme of the novel is cloning and the moral dilemma it raises, NLMG is everything but a straightforward novel with only one purpose. Instead, this multi-faceted novel raises many issues and opens new perspectives on the topics of repression, suppression of feelings, passivity and simulation of life. The message Ishiguro wants to convey is that - human or not - the clones all too easily become slaves to habits and routines. Despite having all necessary prerequisites, they fail to live their lives to the full, hindered by their complete lack of curiosity, stupefied by fear, unwilling to take risks and step into the unknown. The externally and internally imposed restrictions take the best of them, leaving them with no other valid option but to remain brutally and horrendously exploited by the "real" people - the so-called "humans". 


\section{REFERENCES}

Atwood, M. 2005. Brave New World. Slate Magazine. [Internet]. Available at: http://slate. com/id/2116040/ [08.02. 2010].

Cappo, E. 2009. Repression and Displacement in Kazuo Ishiguro's When We Were Orphans and Never Let Me Go. [Internet]. Available at: http://deepblue.lib.umich. edu/bitstream/2027.42/63944/1/cappo_emily_2009.pdf [02.03.2010].

Dewey, J. 1957. Human Nature and Conduct, An Introduction to Social Psychology. New York: The Modern Library.

Ishiguro, K. 2005. Never Let Me Go. London: Faber and Faber.

Ishiguro, K. n.d. Interviewed in Bookbrowse. [Internet]. Available at: http://www. bookbrowse.com/author_interviews/full/index.cfm/author_number/477/KazuoIshiguro [12.01.2011].

Kemp, P. 2005. Never Let Me Go by Kazuo Ishiguro. The Sunday Times.[Internet]. Available at: http://www.entertainment.timesonline.co.uk/tol/arts_and_entertainment/ books/article514753.ece [08.02.2010].

Menand, L. 2005. Something About Kathy. [Internet]. Available at: http://www. newyorker.com/archive/2005/03/28/050328crbo_books1 [03.03.2010].

Messud, C. 2005. Love's Body. The Nation. [Internet]. Available at: http://mydigest. espacioblog.com/post/2006/09/04/claire-messud-love-s-body [03.03.2010].

Mohr, M. et al. 2008. The Preclusion of Rebellion in Never Let Me Go. [Internet]. Available at: http://rudar.ruc.dk/bitstream/1800/3710/1/Final Report.pdf [02.03.2010].

Puchner, M. 2008. When We Were Clones. Raritan Reviews. [Internet]. Available at: http:// www.people.fas.harvard.edu/ puchner/raritanclones.pdf [28.04.2011].

"Sociological Theory/Role Theory". n.d. Wikibooks. [Internet]. Available at: http:// en.wikibooks.org/wiki/Sociological_Theory/Role_Theory [02.03.2010].

Wong, C. F. 2005. Kazuo Ishiguro. Second Edition. Tavistock, Devon: Northcote House Publishers Ltd.

Wood, J. 2005. The Human Difference. The New Republic. [Internet]. Available at: http:// www.powells.com/review/2005_05_12.html [03.03.2010].

\section{SUMMARY}

\section{HUMAN CONDITION IN KAZUO ISHIGURO'S NEVER LET ME GO}

The purpose of this paper is to highlight, through a comprehensive psychological and sociological analysis of characters in Kazuo Ishiguro's novel Never Let Me Go, how roles, rules, habits, and routines, imposed either externally or internally, ultimately take the better of us, making our lives empty and superficial. Ishiguro's characters parentless clones with a "higher" purpose in life, stand as perfect examples of how easy it is to forget what human existence is all about, how easy it is to sink into the bottomless sea of human tragedy, or, as Ishiguro himself once put it - "the sadness of the human condition". The paper utilizes John Dewey's Human Nature and Conduct, and the so-called "role theory", to argue social role versus private life, passivity and 
suppression of feelings, while trying to provide answers to the key questions: why don't the clones rebel and why can't they be human.

KEYWORDS: social roles, habits, passivity, repression, imitation of life, rebellion, human(ity), suppression of feelings.

(Original scientific paper received 31.01.2011; revised 22.08.2011; accepted 12.11.2011) 